\title{
Heavy metals in equine biological components ${ }^{1}$
}

\author{
Maria Verônica de Souza², Maurício Paulo Ferreira Fontes ${ }^{3}$, Raphael Bragança Alves \\ Fernandes $^{3}$
}

\footnotetext{
${ }^{1}$ Research supported by FAPEMIG.

${ }^{2}$ Departamento de Veterinária, Universidade Federal de Viçosa, Viçosa, MG, Brasil.

${ }^{3}$ Departamento de Solos, Universidade Federal de Viçosa, Viçosa, MG, Brasil.
}

\begin{abstract}
The objective of this research was to determine the concentration of heavy metals in the blood ( $\mathrm{Pb}, \mathrm{Ni}$ and $\mathrm{Cd})$, serum $(\mathrm{Cu}$ and $\mathrm{Zn})$ and hair $(\mathrm{Pb}, \mathrm{Ni}, \mathrm{Cd}, \mathrm{Cu}$ and $\mathrm{Zn})$ of horses raised in non-industrial and industrial areas (with steel mill), and to verify the possibility to use these data as indicators of environmental pollution. The samples were collected during summer and winter, aiming to verify animal contamination related to environment and season of the year. Copper and $\mathrm{Zn}$ contents determined in the serum and $\mathrm{Cd}$ and $\mathrm{Ni}$ contents obtained in the blood indicated no contamination effects of industries. For some animals, contents of $\mathrm{Pb}$ in the blood were higher than those considered acceptable for the species, but without relationship with industrialization and without clinical signs of $\mathrm{Pb}$ intoxication. The heavy metals evaluated on the hair of horses in this study were not increased with the presence of industries, but $\mathrm{Cu}$ and $\mathrm{Cd}$ contents were influenced by the season. The contents of some heavy metals in biological components analyzed were influenced by season sampling; however, serum, blood and hair may not be suitable to indicate differences in environmental contamination between the two contrasting areas. Most part of the heavy metal contents was lower or close to the reference values for horses. Serum, blood and hair components from horses may not be effective as indicators of environmental pollution with heavy metals. Industrialization and seasons have no effects on most part of heavy metals contents from those components.
\end{abstract}

Key Words: bio-indicators, environmental monitoring, environmental quality, horses, pollution

\section{Introduction}

Mineral elements are essential for animal health, survival and production (Reis et al., 2010). However, if they are ingested in excessive doses or if they are toxic like heavy metals, they may be harmful and lethal. Specifically for horses, Casteel (2001) review the current concern about poisoning with metals, showing problems such as gastrointestinal upset, hepatopathies, peripheral neuropathy, intermittent colic, mild anemia, as well as diseases related to musculoskeletal system, and kidneys.

Heavy metals are present in everyday activities of men more intensely than many would ever imagine. They originate from several sources that can contaminate soil, water and plants, and consequently, animals (Hammond and Aronson, 1964; Kuno et al., 1999; Patra et al., 2007; Reis et al., 2010; Rajaganapathy et al., 2011) and humans (Duarte and Pasqual, 2000). These sources include atmospheric deposition, farming and cattle-raising residues, fertilizers and soil correctives, agrochemicals, sewage sludge, irrigation water, urban garbage composts, and urban, industrial and mining wastes.

Pastures are in general contaminated by atmospheric deposition, foundries, and various industry and urban wastes (Hammond and Aronson, 1964). Contaminated effluents from different industrial processes or small urban activities can also be responsible for contamination of water for animal use. Proximity to humans, coinciding habitats, and greater organism similarity makes it possible for animals like horses to have the potential to be used as indicators of environmental contamination.

Usually, contamination of animals by heavy metals is not a frequent scientific research topic because priority has been given to studies of the effects of these elements on human health or on some specific environmental compartment, such as soil, sediments, vegetation and water. The use of different soft tissues and blood of animals can be a way to evaluate the concentration of heavy metals in the animal body. In addition, the hair analysis has been utilized to investigate or monitor human and animal exposure to a number of toxic heavy metals (Ward and Savage, 1994; Patra et al., 2007). The objective of this research was to evaluate the heavy metal contamination in biological components of horses from two environmentally different regions and in two seasons. In addition, it was aimed to verify the possibility to use the results as indicators of environmental pollution. 


\section{Material and Methods}

This work was approved by the Ethics Committee of Veterinary Department of Universidade Federal de Viçosa, and the assays are in agreement with the Veterinary Professional Ethics Code, with the Ethical Principles for Animal Research established by Colégio Brasileiro de Experimentação Animal and with current Brazilian legislation.

Horses originated from two distinct areas were used in this study, displaying the following characteristics: Non-industrial area (control area): horses selected in the rural area of the municipality of Viçosa (MG, Brazil), on farms over $3 \mathrm{~km}$ distant from the urban area. Only animals which were kept semi-stabled for at least one year were selected. Industrial area: animals raised close to smelters in Sete Lagoas (MG, Brazil) and Prudente de Morais (MG, Brazil). The horses had been utilized for field work and were pasture-raised for at least one year.

Animals from non-industrialized area were only females, and those from industrial area were of both sexes. In both groups, the animals were from different breeds and ages (2-19 years, average of 9.7). Each group was formed by 20 randomly selected clinically healthy animals, from which blood, serum, and hair samples were collected twice a year, with two samplings performed: one during late winter and the other during late summer.

The two areas evaluated are located in the state of Minas Gerais, in southeastern Brazil. The climate in both regions is characterized by hot rainy summers and dry winters. Mean annual temperature and rainfall in the nonindustrial and industrial areas are $18.5^{\circ} \mathrm{C}$ and $1.220 \mathrm{~mm}$ and $22.9^{\circ} \mathrm{C}$ and $1.400 \mathrm{~mm}$, respectively.

At the sampling places, detailed individual information data was obtained on equine (sex, age, breed, weight, main use) and farm management. After that, the animals were subjected to physical exam including nutritional status, degree of hydration, mucous membrane color, capillary refill time, and heart and respiratory rates.

The 40 animals included in the study were well hydrated with normal mucous. The heart and respiratory rates, as well as the capillary refill time were within the reference standards for the species (Loving, 2003; Southwood, 2006; Baxter, 2009). Mean body score, based on classification of Speirs (1999) was 3, on a scale from 0 to 5, meaning a good body condition. One of the horses (industrial area) was certified dead due to a snake bite. Thus, in the summer collection, total equine number accounted to 39 animals.

For the biological sampling procedure, $10 \mathrm{~mL}$ of blood were collected from each animal by puncturing the jugular vein to vacuum glass tubes containing sodium heparin to analyze $\mathrm{Pb}, \mathrm{Cd}$ and $\mathrm{Ni}$ concentrations. To analyze $\mathrm{Cu}$ and $\mathrm{Zn}$, another $10 \mathrm{~mL}$ of blood were collected to glass tubes without anticoagulant and immediately after collection, these samples were subjected to sedimentation at room temperature, followed by centrifugation $(1720 \mathrm{x} \mathrm{g}$, over 10 minutes) to obtain the serum, which was collected, identified and stored under refrigeration until analytical procedure.

To determine the $\mathrm{Pb}$ and $\mathrm{Ni}$ in each blood sample, $0.2 \mathrm{~mL}$ was taken and diluted with $1.8 \mathrm{~mL}$ aqueous solution containing $0.1 \%$ Triton X-100 and $0.2 \%$ nitric acid (Kuno et al., 1999). To estimate $\mathrm{Cd}$ contents, the blood samples were subjected to nitroperchloric digestion $(3: 1, \mathrm{v} / \mathrm{v})$ at $150{ }^{\circ} \mathrm{C}$. For content quantification of $\mathrm{Zn}$ and $\mathrm{Cu}$, the serum samples were diluted 5 times in Milli-Q water (Jian-Xin, 1990). The elements $\mathrm{Pb}$ and $\mathrm{Ni}$ in the extracts were determined by graphite furnace atomic absorption spectrometry; $\mathrm{Cu}$ and $\mathrm{Zn}$ by flame atomic absorption spectrometry and $\mathrm{Cd}$ by inductively coupled plasma optical emission spectroscopy (ICP-OES). The results were expressed as $\mu \mathrm{g} \mathrm{mL}^{-1}$.

Samples of $10 \mathrm{~g}$ of the mane and tail hair were collected using stainless steel surgical scissors. Only samples from the nape area nearest to the skin were collected, identified, and stored in plastic bags. Then, they were cut into fragments of approximately $0.3 \mathrm{~cm}$ and washed four times with 1:200 (v/v) dilution of Triton X-100 solution to remove exogenous elements, rinsed twice with isopropylalcohol and allowed to drain. This was followed by rinses with Milli-Q water and two more rinses with acetone, and then they were allowed to drain. Finally, the samples were dried on a hot plate (Asano et al., 2002). For determination and digestion of the heavy metal contents, the hair samples were processed by following the technique described by Pimenta and Vital (1994). Thus, after drying, $0.4000 \mathrm{~g}$ of the samples was solubilized in $10 \mathrm{~mL}$ of concentrated nitric acid on a hot plate. After gentle boiling for $30 \mathrm{~min}, 2 \mathrm{~mL}$ of hydrogen peroxide $(30 \%)$ were added. Once the volumes were reduced until close to drying, the solutions were cooled, transferred to $10 \mathrm{~mL}$ volumetric balloons and the volumes were completed with Milli-Q water. The extracts obtained were analyzed by ICP-OES and the results were expressed as $\mu \mathrm{g} \mathrm{g}^{-1}$.

In the serum, the limits of detection were $0.002 \mathrm{mg} \mathrm{mL}^{-1}$ for $\mathrm{Zn}$ and $0.004 \mathrm{mg} \mathrm{mL}^{-1}$ for $\mathrm{Cu}$. In the blood, they were $0.002 \mathrm{mg} \mathrm{mL}^{-1}$ for $\mathrm{Cd}$ and $\mathrm{Ni}$, and $0.010 \mathrm{mg} \mathrm{mL}^{-1}$ for $\mathrm{Pb}$. In the hair, $0.001,0.015,0.016,0.021$ and $0.033 \mathrm{mg} \mathrm{g}^{-1}$ for $\mathrm{Cd}$, $\mathrm{Pb}, \mathrm{Ni}, \mathrm{Cu}$ and $\mathrm{Zn}$, respectively.

The experimental design consisted of a completely randomized $2 \times 2$ factorial arrangement (two areas and 
two seasons). Data obtained were subjected to statistical analysis using the SAEG software (version 9.1, 2007). A descriptive statistical analysis of the data was conducted, followed by analysis of variance (ANOVA). The effects of the areas (industrial or non-industrial) and seasons of the year (winter or summer) on the heavy metal content in the blood ( $\mathrm{Pb}, \mathrm{Cd}$ and $\mathrm{Ni})$, serum ( $\mathrm{Cu}$ and $\mathrm{Zn})$ and hair $(\mathrm{Cu}, \mathrm{Zn}$, $\mathrm{Pb}, \mathrm{Cd}$ and $\mathrm{Ni}$ ) were assessed by the Tukey test $(\mathrm{P}<0.05)$. When detected, the interactions between areas and seasons evaluated were deployed.

\section{Results}

The areas and seasons evaluated affected $\mathrm{Cu}$ contents on serum samples. Animals from industrial area had higher $(\mathrm{P}<0.05)$ metal contents than those from control area and in the summer, higher contents of $\mathrm{Cu}$ were observed in the serum of the horses (Table 1). With respect to $\mathrm{Zn}$, analysis of the deployment of the interaction indicated an important effect of season on the contents obtained (Table 2), with higher contents of this heavy metal in the winter and summer $(\mathrm{P}<0.05)$, for non-industrial and industrialized areas, respectively. On the other hand, in the summer sampling, there were no differences in $\mathrm{Zn}$ contents between the two areas evaluated, and in the winter sampling, horses from non-industrialized area had higher serum levels of the metal.

Concentrations of $\mathrm{Pb}, \mathrm{Cd}$ and $\mathrm{Ni}$ were observed in the blood. Areas and seasons did not influence the contents of $\mathrm{Cd}(\mathrm{P}<0.05)$, and $65 \%$ of the analyzed samples indicated levels below the detection limit. There was no effect of areas on the $\mathrm{Pb}$ and $\mathrm{Ni}$ contents. However, as occurred for $\mathrm{Cu}$ contents in the serum, higher concentrations $(\mathrm{P}<0.05)$ of both metals were obtained in the summer. In the winter, the concentrations obtained were lower if compared with the summer, and considering the $\mathrm{Ni}$, the mean value was below the detection limit.

All heavy metals evaluated were present in the hair of the horses. The different areas and seasons studied did not influence the contents of $\mathrm{Pb}$ and $\mathrm{Ni}(\mathrm{P}<0.05)$, with $82 \%$ and $92 \%$ of samples analyzed presenting levels below the detection limits, respectively. The contents of $\mathrm{Cu}$ and $\mathrm{Cd}$ in the hair were not affected by areas, although higher concentrations were observed in summer and winter $(\mathrm{P}<0.05)$, respectively. Similarly to serum, the $\mathrm{Zn}$ contents in the hair were influenced by the interaction area and

Table 1 - Mean heavy-metal contents in biological components of horses, as a function of the area and season of sampling

\begin{tabular}{|c|c|c|c|c|c|c|c|}
\hline & & & & & & & \\
\hline & & $\begin{array}{c}\text { Non-industrial } \\
\left(\mathrm{N}=40^{\#}\right)\end{array}$ & $\begin{array}{c}\text { Industrial } \\
(\mathrm{N}=39)\end{array}$ & & $\begin{array}{l}\text { Winter } \\
(\mathrm{N}=40)\end{array}$ & $\begin{array}{c}\text { Summer } \\
(N=39)\end{array}$ & $\mathrm{A} \times \mathrm{S}$ \\
\hline $\begin{array}{l}\text { Serum } \\
\left(\mu \mathrm{g} \mathrm{mL}^{-1}\right)\end{array}$ & $\mathrm{Cu}$ & $\begin{array}{c}1.033 \mathrm{~B} \\
(0.270-3.419)\end{array}$ & $\begin{array}{c}1.447 \mathrm{~A} \\
(0.845-6.209)\end{array}$ & & $\begin{array}{c}0.730 \mathrm{~b} \\
(0.270-1.240)\end{array}$ & $\begin{array}{c}1.757 \mathrm{a} \\
(1.169-6.209)\end{array}$ & ns \\
\hline & $\mathrm{Zn}$ & $\begin{array}{c}0.696 \\
(0.345-1.235)\end{array}$ & $\begin{array}{c}0.620 \\
(0.240-2.145)\end{array}$ & & $\begin{array}{c}0.563 \\
(0.240-1.235)\end{array}$ & $\begin{array}{c}0.757 \\
(0.345-2.145)\end{array}$ & $*$ \\
\hline $\begin{array}{l}\text { Blood } \\
\left(\mu \mathrm{g} \mathrm{mL}^{-1}\right)\end{array}$ & $\mathrm{Pb}$ & $\begin{array}{c}1.058 \\
(<\mathrm{dl}-3.680)\end{array}$ & $\begin{array}{c}1.082 \\
(<\mathrm{dl}-3.680)\end{array}$ & & $\begin{array}{c}0.013 \mathrm{~b} \\
(<\mathrm{dl}-0.039)\end{array}$ & $\begin{array}{c}2.154 \mathrm{a} \\
(<\mathrm{dl}-3.680)\end{array}$ & ns \\
\hline & $\mathrm{Cd}$ & & & $\begin{array}{c}0.005 \\
(<\mathrm{dl}-0.060)\end{array}$ & & & ns \\
\hline & $\mathrm{Ni}$ & $\begin{array}{c}0.006 \\
(<\mathrm{dl}-0.100)\end{array}$ & $\begin{array}{c}0.006 \\
(<\mathrm{dl}-0.100)\end{array}$ & & $<\mathrm{dlb}$ & $\begin{array}{c}0.011 \mathrm{a} \\
(<\mathrm{dl}-0.100)\end{array}$ & $\mathrm{ns}$ \\
\hline $\begin{array}{l}\text { Hair } \\
\left(\mu \mathrm{g} \mathrm{g}^{-1}\right)\end{array}$ & $\mathrm{Cu}$ & $\begin{array}{c}5.7 \\
(3.6-19.4)\end{array}$ & $\begin{array}{c}6.5 \\
(2.3-10.7)\end{array}$ & & $\begin{array}{c}5.2 \mathrm{~b} \\
(2.3-7.7)\end{array}$ & $\begin{array}{c}6.7 \mathrm{a} \\
(4.4-19.4)\end{array}$ & $\mathrm{ns}$ \\
\hline & $\mathrm{Zn}$ & $\begin{array}{c}172.1 \\
(133.4-240.9)\end{array}$ & $\begin{array}{c}164.2 \\
(78.2-256.1)\end{array}$ & & $\begin{array}{c}153.4 \\
(78.2-256.1)\end{array}$ & $\begin{array}{c}183.4 \\
(133.4-218.7)\end{array}$ & $*$ \\
\hline & $\mathrm{Pb}$ & & & $\begin{array}{c}0.022 \\
(<\mathrm{dl}-0.243)\end{array}$ & & & ns \\
\hline & $\mathrm{Cd}$ & $\begin{array}{c}0.018 \\
(<\mathrm{dl}-0.045)\end{array}$ & $\begin{array}{c}0.022 \\
(<\mathrm{dl}-0.078)\end{array}$ & & $\begin{array}{c}0.039 \mathrm{a} \\
(0.020-0.078)\end{array}$ & $<\mathrm{dlb}$ & $\mathrm{ns}$ \\
\hline & $\mathrm{Ni}$ & & & $\begin{array}{c}0.005 \\
(<\mathrm{dl}-0.157)\end{array}$ & & & ns \\
\hline
\end{tabular}

The results presented are the mean (minimum-maximum); $<\mathrm{dl}$ : below the detection limit. In calculating the means and statistical analysis, the values $<\mathrm{dl}$ were considered as zero. According to the Tukey test $(\mathrm{P}<0.05)$, means of heavy metals followed by the same capital letter, and means followed by the same lowercase letter, both in the row, do not differ for the area and season, respectively.

$\mathrm{A} \times \mathrm{S}$ - interaction evaluated between area and season of sampling (ns - not significant, $*: \mathrm{P}<0.05$ )

For significant interactions, means were not compared, and deployments are presented in Table 2 .

\#: death of animal. 
Table 2 - Zinc contents in biological components of horses after deploying interactions of areas and seasons of sampling

\begin{tabular}{lccccc}
\hline & \multicolumn{2}{c}{ Non-industrial area } & & \multicolumn{2}{c}{ Industrial area } \\
\cline { 2 - 3 } \cline { 5 - 6 } & $\begin{array}{c}\text { Winter } \\
(\mathrm{N}=20)\end{array}$ & $\begin{array}{c}\text { Summer } \\
(\mathrm{N}=19)\end{array}$ & & $\begin{array}{c}\text { Winter } \\
(\mathrm{N}=20)\end{array}$ & $\begin{array}{c}\text { Summer } \\
(\mathrm{N}=19)\end{array}$ \\
\hline Serum $\left(\mu \mathrm{g} \mathrm{mL}^{-1}\right)$ & $0.778 \mathrm{Aa}$ & $0.615 \mathrm{~B}$ & & $0.349 \mathrm{Bb}$ & $0.906 \mathrm{~A}$ \\
Hair $\left(\mu \mathrm{g} \mathrm{g}^{-1}\right)$ & $162.9 \mathrm{Ba}$ & $181.4 \mathrm{~A}$ & & $144.0 \mathrm{Bb}$ & $185.5 \mathrm{~A}$ \\
\hline
\end{tabular}

According to the Tukey Test $(\mathrm{P}<0.05)$, in the same area, means of heavy metals followed by the same capital letter in the row do not differ among themselves, and means followed by the same lowercase letter in the row, do not differ for season.

season. Again, season influenced this heavy metal content, with higher values verified in the summer $(\mathrm{P}<0.05)$ for both areas evaluated. Also similarly to the serum, differences in the $\mathrm{Zn}$ contents in hair samples were observed only for the winter, when the horses of non-industrial area showed higher levels of the metal.

\section{Discussion}

Copper contents in serum were affected by areas and seasons (Table 1). Even though data show higher $\mathrm{Cu}$ contents in the industrial area, as also observed for pastureraised animals by Maia et al. (2006), the mean contents for both areas were close to or within normality range expected for horses, considering 1.04-1.77 $\mu \mathrm{g} \mathrm{mL}^{-1}$, as defined by Thompson (1992) or considering the 0.5-1.5 $\mu \mathrm{g} \mathrm{mL}^{-1}$ used by Wichert et al. (2002). Thus, the results do not show clear effects of industrial activities on the serum $\mathrm{Cu}$ contents of horses.

Zinc contents in the serum were not affected by industrial area (Table 1). On the other hand, the control area showed higher contents than the industrialized area when sampling was carried during winter, and no differences were observed between the two areas in the summer (Table 2). In fact, the contents measured were lower or close to the reference values $\left(0.77-1.19 \mu \mathrm{g} \mathrm{mL}^{-1}\right)$ defined by Thompson (1992) for horses or those adopted (0.6-1.2 $\mu \mathrm{g} \mathrm{mL}^{-1}$ ) by Wichert et al. (2002) in their study with 106 horses from Bavaria. In a first analysis, these results raise a concern, since this element is essential for enzymatic metabolism, and it is involved in protein synthesis and carbohydrate metabolism (Marçal et al., 2003a). However, Wichert et al. (2002) reported that $31 \%$ of the animals studied also presented $\mathrm{Zn}$ contents in serum below reference values, but as verified in the present study, no animals showed specific signs of zinc deficiency. This lower concentration of $\mathrm{Zn}$ in the serum may be related to absence of mineral supplementation or to small amounts of salt mixed in the feed. Other factors related to low $\mathrm{Zn}$ serum contents include environment and physiology, which can lead to variations in the concentration of $\mathrm{Zn}$ in horses (Auer et al., 1988). Birick et al. (2005) showed that seasonal and diet changes have important effects on the concentration of this element in equine serum. On the other hand, the mean contents obtained in this study were higher than those considered normal for equines $\left(0.47 \pm 0.09 \mu \mathrm{g} \mathrm{mL}^{-1}\right)$ by Auer et al. (1988), who studied 83 clinically healthy horses in Australia.

Although industrialization did not affect the levels of $\mathrm{Cu}$ and $\mathrm{Zn}$ in the serum, some animals presented high contents of these heavy metals in their serum, surpassing the highest reference values of 1.77 and $1.19 \mu \mathrm{g} \mathrm{mL}^{-1}$ defined by Thompson (1992) for $\mathrm{Cu}$ and $\mathrm{Zn}$, respectively. For $\mathrm{Cu}$ contents, all highest values were obtained in the summer for five animals in industrialized area and for two animals in control area. For $\mathrm{Zn}$ contents, only one animal per area showed higher values than the references, but in different seasons. This result, especially for $\mathrm{Cu}$, may suggest some effect of industrialization on the environmental contamination, affecting only a few individuals.

The lead toxicity values in blood for farm animals are always lower than those in humans (Marçal et al., 2003b). In horses, the concentration of $0.25 \mu \mathrm{g} \mathrm{mL}^{-1}$ is accepted as maximum limit, while in humans, a maximum of $0.60 \mu \mathrm{g} \mathrm{mL}^{-1}$ is adopted (Gilman, 1991). In a study carried out in India with 288 horses from three different areas (industrial, highway adjacent and rural zone), the mean $\mathrm{Pb}$ contents in serum were $0.47 \pm 0.02,0.55 \pm 0.02$ and $0.38 \pm 0.03 \mu \mathrm{g} \mathrm{mL}^{-1}$, respectively (Dey and Dwivedi, 2004). These authors emphasized the non-observation of clinical signs associated with intoxication by this heavy metal in the studied animals. On the other hand, a study conducted with horses living on farmland in the vicinity of non-ferrous metal smelters in China (Liu, 2003) showed signs of intoxication by $\mathrm{Pb}$ in 10 horses, which presented mean contents in the serum of $0.28 \pm 0.10 \mu \mathrm{g} \mathrm{mL}^{-1}$. In addition, Palacios et al. (2002) reported $\mathrm{Pb}$ contents of 0.20 to $0.89 \mathrm{mg} \mathrm{kg}^{-1}$ in blood samples taken from six dead horses with diagnosis of lead poisoning.

Thompson (1992) considers normal animals with serum $\mathrm{Pb}$ contents lower than $0.10 \mu \mathrm{g} \mathrm{mL}^{-1}$, but concentrations equal to or higher than $0.30 \mu \mathrm{g} \mathrm{mL}^{-1}$, when accompanied by clinical signs, are compatible with intoxication in horses.

Some horses included in this study showed blood $\mathrm{Pb}$ contents higher than those considered acceptable for the species, but without relationship with industries presence. The maximum value $\left(0.60 \mu \mathrm{g} \mathrm{m}^{-1}\right)$ indicated by Gilman (1991) was surpassed by 15 animals in industrial area, but also by 15 animals in control area. In all cases, these high 
values were obtained in the summer, which defined the statistically confirmed high values in this season $(\mathrm{P}<0.05$, Table 1). However, no clinical signs of $\mathrm{Pb}$ intoxication were found on animals. High contents as observed for these animals are not expected, even with $\mathrm{Pb}$ addition to the feed, as provided by Dollahite et al. (1978), who added daily doses of 6.25 to $12.2 \mathrm{mg} \mathrm{kg}^{-1}$ of $\mathrm{Pb}$ acetate during 105 days and still no clinical signs were observed. The blood $\mathrm{Pb}$ contents at the end of the evaluation period varied from 0.35 to $0.75 \mu \mathrm{g} \mathrm{L}^{-1}$. Deaths of horses occurred only when daily supplemental doses were provided for an additional period of 190 days.

The cadmium contents obtained in the blood were low although there are no data in the literature about reference values. The mean $\mathrm{Cd}$ content in the blood samples of the present study $\left(0.005 \mu \mathrm{g} \mathrm{mL}^{-1}\right)$ was below the range from 0.0075 to $0.0158 \mu \mathrm{g} \mathrm{mL}^{-1}$ observed in horses by Bianu (2004) in some polluted areas in Romania. Clinical signs of $\mathrm{Cd}$ intoxication are not common, but were observed by Liu (2003) in animals raised near an industrial area, which presented mean serum contents of $0.17 \pm 0.04 \mu \mathrm{g} \mathrm{mL} \mathrm{m}^{-1}$. The contents reported in these last studies indicate no Cd contamination effects of industries on the evaluated animals. Although five horses of this study presented $\mathrm{Cd}$ contents higher than the maximum value verified by Bianu (2004), three in non-industrialized area and two in the industrialized one, the concentrations obtained are low and do not merit concern. This evidence contrasts with Erlinder and Piscador (1978), who commented that horses are valuable as models for research on humans, in relation to the effects of $\mathrm{Cd}$ on metabolism, and with a study of Maia et al. (2006), who indicated the potential of blood Cd contents for bio-indicator of environmental pollution.

The higher $\mathrm{Pb}$ contents and lower Cd observed in blood samples contrasted with the ratio expected between both metals, as suggested by Ward and Savage (1994), who found for these two elements elevated and correlated contents for animals raised close to a motorway in England.

Reference values of blood Ni concentrations are also not common in the literature. In the present study, the mean $\mathrm{Ni}$ contents were low, and the difference observed between seasons seems not to be relevant. Low and similar mean contents indicated no industrialization effects on $\mathrm{Ni}$ contamination in horses.

In humans, hair is considered an important indicator to quantify the degree of exposure to toxic substances and pollutants, and it may be effectively used to monitor and prevent environmental pollution (Chojnacka et al., 2012). For horses, hair analysis has been indicated for different purposes, varying from assessing nutritional status to environmental poisoning evaluation, as reviewed by Dunnett (2005).

Of the heavy metals evaluated on horse hair in this study, $\mathrm{Cu}, \mathrm{Pb}, \mathrm{Cd}$ and $\mathrm{Ni}$ contents did not increase with the presence of industries. Copper and $\mathrm{Cd}$ contents were influenced by season, and $\mathrm{Pb}$ and $\mathrm{Ni}$ did not show any difference between contrasted areas and seasons.

The hair $\mathrm{Cu}$ mean contents obtained in this study were close to the $4.8 \pm 1.3 \mu \mathrm{g} \mathrm{g}^{-1}$ obtained by Asano et al. (2002) for the hair of 24 healthy thoroughbred racing horses from Japan, and slightly lower than the $7.3 \pm 1.7 \mu \mathrm{g} \mathrm{g}^{-1}$, observed by Wichert et al. (2002) for 106 horses from Germany. The authors from those studies indicated their values as reference to healthy animals or very similar to data previously reported from horses without clinical signs of contamination, or even as associated with normal range. Therefore, the difference $(\mathrm{P}<0.05)$ verified between evaluated seasons in the present study do not indicate deviation from normal pattern on hair $\mathrm{Cu}$ contents.

Hair is considered by Regius-Mocsenyi (1990) as one of the best ways of estimating body concentration of $\mathrm{Zn}$ in horses. Although within each area studied, sample collection in the summer produced higher $\mathrm{Zn}$ hair contents, data show absence of clear effect by surrounding on contents in this biological component. Considering only samples analyzed in the winter, the control area presented higher contents than the industrial area.

The mean hair $\mathrm{Zn}$ contents obtained in this study were close to the $126 \pm 38 \mu \mathrm{g} \mathrm{g}^{-1}$ reported by Wichert et al. (2002) for 106 horses from Germany, and considered within normal range. On the other hand, the mean results found in this study were higher than those obtained by Bianu (2004) in horses from polluted areas in Romania (47.5$53.5 \mu \mathrm{g} \mathrm{g}^{-1}$ ), by Asano et al. (2002), in 24 Japanese healthy racing horses $\left(86 \pm 24 \mu \mathrm{g} \mathrm{g}^{-1}\right)$, and by Farmer and Farmer (2000), for horses raised around a metal production center in eastern Kazakhstan $\left(112.70 \pm 6.29 \mu \mathrm{g} \mathrm{g}^{-1}\right)$.

Pourjafar et al. (2008) showed association between contamination and hair $\mathrm{Pb}$ presence, after evidence of negative relationship between hair $\mathrm{Pb}$ contents and distance from pollution source in Iran. The authors suggested a certain potential for using horse hair as a bio-indicator of environmental pollution. However, the $\mathrm{Pb}$ contents in hair obtained in this study do not support this suggestion. The data showed low $\mathrm{Pb}$ contents in both areas, especially if compared with the mean values $\left(0.93 \pm 0.78 \mu \mathrm{g} \mathrm{g}^{-1}\right)$ obtained by Asano et al. (2002) for 24 healthy racing horses from Japan, but also if compared with the ranges measured by Janiszewska and Cieśla (2002) in 79 horses from Poland in the winter ( 0.0 to $2.46 \mu \mathrm{g} \mathrm{g}^{-1}$ ) and summer ( 0.0 to $10.7 \mu \mathrm{g} \mathrm{g}^{-1}$ ). 
It is very likely that the industrial regions evaluated do not present sources of $\mathrm{Pb}$ contamination because it is common to identify the presence of this metal in biological compartments when it is present in the environment. This reasoning is supported by the results obtained by Bianu (2004), who reported $\mathrm{Pb}$ contents from 47.5 to $53.5 \mu \mathrm{g} \mathrm{g}^{-1}$ in hair of horses raised in heavy-metal polluted areas in Romania.

Cadmium contents in hair samples were only affected by season, because the results from summer revealed mean values below the detection limit. This observation contrasts with data from Janiszewska and Cieśla (2002), who observed higher $\mathrm{Cd}$ contents when collecting hair samples in the summer ( 0.039 to $\left.0.997 \mu \mathrm{g} \mathrm{g}^{-1}\right)$ than in the winter $(0.0$ to $\left.0.111 \mu \mathrm{g} \mathrm{g}^{-1}\right)$ for 79 horses from Poland. Nevertheless, our data were lower than or close to those reported by those authors, and much lower than the $0.12 \pm 0.12 \mu \mathrm{g} \mathrm{g}^{-1}$ obtained by Asano et al. (2002) with 24 healthy racing horses in Japan. If the range from 1.2 to $2.4 \mu \mathrm{g} \mathrm{g}^{-1}$ obtained from polluted areas in Romania studied by Bianu (2004) is considered, the data obtained in the present research suggest the absence of $\mathrm{Cd}$ contamination in the examined areas.

No differences were observed in the $\mathrm{Ni}$ contents in the hair samples examined in both areas and seasons, and the mean obtained was much lower than the $0.0378 \mu \mathrm{g} \mathrm{g}^{-1}$ (0.084-1.80 $\left.\mu \mathrm{g} \mathrm{g}^{-1}\right)$ reported by Topczewska (2012) for 20 mares from Poland, and mainly much lower than the $0.55 \pm 0.65 \mu \mathrm{g} \mathrm{g}^{-1}$ obtained by Asano et al. (2002) with 24 healthy racing Japanese horses.

The data obtained show samples collected in the summer with high contents of heavy metals in comparison with those collected in the winter for $\mathrm{Cu}$ (serum and hair) and $\mathrm{Pb}$ (blood). On the other hand, high content in samples obtained in the winter was verified for $\mathrm{Cd}$ (hair). No differences between seasons were observed on serum ( $\mathrm{Zn})$, blood $(\mathrm{Cd})$ and hair $(\mathrm{Zn}, \mathrm{Pb}$ and $\mathrm{Ni})$. Differences between seasons were not considered relevant for Ni (blood). These results suggest that there is no clear trend related to the samples collection in different seasons on the contents of heavy metals in equine biological components.

Considering all results obtained in this study, it is difficult to recommend the biological components evaluated as adequate indicators of environmental pollution. However, it is important to consider the possibility of absence of recent contaminations in the surroundings of the industrial area examined, because one should not overlook recent efforts developed by the industrial sector to reduce and control environmental pollution. The reduction of atmospheric emissions and residue production may have contributed to the absence of significant differences between the two areas evaluated. As far as the collection of samples effects are concerned, the differences observed in contents between the two evaluated seasons seem to be irrelevant, because the values obtained in summer and winter were not clearly out of the range values for the species. Effects of season were observed by Janiszewska and Cieśla (2002) and Topczewska (2012) in their study with horses for some of the heavy metals analyzed here, and indicated the need for future studies on this matter. However, studies like the present one provide helpful data for a necessary dataset to guide future initiatives on monitoring and assessing environmental pollution given the lack of elements composition on animal biological components, especially for tropical conditions.

\section{Conclusions}

Serum, blood and hair components from equines may not be effective as indicators of environmental pollution with heavy metals. Industrialization and seasons have no effects on most part of heavy-metal contents from those components. The high contents of heavy metals presented for a few individuals cannot be associated with industrialization or clinical signs of intoxication either. However, the data presented can help future initiatives on monitoring and assessment of environmental pollution using animals, because there is an almost complete lack of information about elements composition on animal biological components, especially for tropical conditions.

\section{Acknowledgments}

The authors thank Fundação de Amparo à Pesquisa do estado de Minas Gerais (FAPEMIG) for the financial support, and Conselho Nacional de Desenvolvimento Científico e Tecnológico ( $\mathrm{CNPq}$ ) for providing research fellowships, as well as Embrapa Milho e Sorgo and Fazenda Experimental Santa Rita (Epamig-FESR), for supporting the collection of samples.

\section{References}

Asano, R.; Suzuki, K.; Otsuka, T; Otsuka, M. and Sakurai, H. 2002. Concentrations of toxic metals and essential minerals in the mane hair of healthy racing horses and their relation to age. Journal of Veterinary Medical Science 64:607-610.

Auer, D. E.; Ng, J. C. and Seawright, A. A. 1988. Assessment of copper and zinc status of farm horses and training Thoroughbreds in south-east Queensland. Australian Veterinary Journal 65:317-320.

Baxter, G. M. 2009. The steps in assessing a colicky horse. Veterinary Medicine 87:1012-1018.

Bianu, E. 2004. Cadmium and lead levels on horse blood and hair in a heavy metals polluted area of Romania. The Veterinary Bulletin 14:91-98. 
Birick, H.; Ocal, N.; Gucus, A. I.; Ediz, B. and Uzman, M. 2005. Seasonal changes of some mineral status in mares. Journal of Equine Veterinary Science 25:346-348.

Casteel, S. W. 2001. Metal toxicosis in horses. Veterinary Clinics of North America: Equine Practice 17:517-527.

Chojnacka, K.; Saeid, A.; Michalak, I. and Mikulewicz, M. 2012. Effects of local industry on heavy metals content in human hair. Polish Journal of Environmental Studies 21:1563-1570.

Dey, S. and Dwivedi, S. K. 2004. Lead in blood of urban Indian horses. Veterinary and Human Toxicology 46:194-195.

Dollahite, J. W.; Younger, R. L.; Crookshank, H. R.; Jones, L. P. and Petersen, H. D. 1978. Chronic lead poisoning in horses. American Journal of Veterinary Research 39:961-964.

Duarte, R. P. S. and Pasqual, A. 2000. Avaliação do cádmio (Cd), chumbo $(\mathrm{Pb})$, níquel $(\mathrm{Ni})$ e zinco $(\mathrm{Zn})$ em solos, plantas e cabelos humanos. Energia na Agricultura 15:46-58.

Dunnett, M. 2005. The diagnostic potential of equine hair: a comparative review of hair analysis for assessing nutritional status, environmental poisoning, and drug use and abuse. p.85-106. In: Advances in equine nutrition - III. Pagan, J. and Geor, R.J., eds. Kentucky Equine Research, Kentucky.

Erlinder, C. G. and Piscator, M. 1978. Cadmium and zinc relationships. Environmental Health Perspectives 25:129-132.

Farmer, A. A. and Farmer, A. M. 2000. Concentration of cadmium, lead and zinc in livestock feed and organs around a metal production centre in eastern Kazakhstan. Science of the Total Environment 257:53-60.

Gilman, A. 1991. Metais pesados e seus antagonistas. p.1061-1065. In: As bases farmacológicas da terapêutica. Klaassen, C. D., ed. Guanabara Koogan, Rio de Janeiro.

Hammond, P. B. and Aronson, A. L. 1964. Lead poisoning in cattle and horses in the vicinity of a smelter. Annals of New York Academy Science 111:595-611.

Janiszewska, J. and Cieśla, A. 2002. Concentration of cadmium and lead in horse blood serum and hair in relation to season and environment. Electronic Journal of Polish Agricultural Universities 5(1). Available at: <http://www.ejpau.media.pp.1/volume5/issue1/ animal/art-06.html >. Accessed on: Feb.15, 2013.

Jian-Xin, Q. I. 1990. Determination of $\mathrm{Cu}, \mathrm{Zn}, \mathrm{Fe}, \mathrm{Ca}, \mathrm{Mg}, \mathrm{Na}$ and $\mathrm{K}$ in serum flame by atomic absorption spectroscopy. Varian Instruments at Work's. AA-93. 2p. Available at: <http://www. ccsservices.ru/lab/res/aa093_3.pdf>. Accessed on: May 24, 2013.

Kuno, R.; Fernicola, N.A.G.G.; Roquetti-Humayta, M. H.; Campos A. E. M. and Filha, M. T. O. 1999. Lead concentration in blood samples of humans and animals near industrial waste dump in São Paulo, Brazil. Veterinary and Human Toxicology 41:249-250.

Liu, Z. P. 2003. Lead poisoning combined with cadmium in sheep and horses in the vicinity of non-ferrous metal smelters. Science of the Total Environment 309:117-126.

Loving, N. S. 2003. Surviving colic. The horse 11:52-62.
Maia, L.; Souza, M. V.; Fernandes, R. B. A; Fontes, M. P. F.; Viana, M. W. S. and Luz, W. V. 2006. Heavy metals in the horse blood, serum, and feed in Minas Gerais, Brazil. Journal of Equine Veterinary Science 26:578-583.

Marçal, W. S.; Gaste, L.; Nascimento, M. R. L.; Liboni, L. and Gomes G. P. 2003a. Cadmium concentration in mineral salt mixtures used as supplementation in beef cattle food. Veterinarski Archiv 73:47-53.

Marçal, W. S.; Villegas-Navarro, A.; Nascimento, M. R. L.; Guerra A. P.; Fujihara, C. J. and Bruschi, A. B. M. 2003b. Bovinos e eqüinos como bioindicadores da poluição ambiental. Revista Brasileira de Ciência Veterinária 10:16-20.

Palacios, H.; Iribarren, I.; Olalla, M. J. and Cala, V. 2002. Lead poisoning of horses in the vicinity of a battery recycling plant. Science of the Total Environment 290:81-89.

Patra, R. C.; Swarup, D.; Naresh, R; Kumar, P.; Nandi, D.; Shekhar, P.; Roy, S. and Ali, S. L. 2007. Tail hair as an indicator of environmental exposure of cows to lead and cadmium in different industrial areas. Ecotoxicology and Environmental Safety 66:127-131.

Pimenta, A. S. and Vital, B. R. 1994. Contaminação de pintores profissionais por metais pesados provenientes de tintas e vernizes. Química Nova 17:277-80.

Pourjafar, M.; Badiei, K.; Shakhse-Niaie, M. 2008. Horse hair as an indicator of $\mathrm{Pb}$ pollution around Shiraz Oil Industry, Iran. Journal of Environmental Science and Technology 1:42-46.

Rajaganapathy, V.; Xavier, F.; Sreekumar, D. and Mandal, P. K. 2011. Heavy metal contamination in soil, water and fodder and their presence in livestock and products: a review. Journal of Environmental Science and Technology 4:234-249.

Regius-Mocsenyi,A. 1990.Zn, Mn, Cu, Mo, Ni and Cd supplementation of cattle, sheep and horses. 1. Zn supplementation. Allattenyesztes es Takarmanyozas 39:255-270.

Reis, L. S. L. S.; Pardo, P. E.; Camargos, A. S. and Oba, E. 2010. Mineral element and heavy metal poisoning in animals. Journal of Medicine and Medical Sciences 1:560-579.

Southwood, L. L. 2006. Acute abdomen. Clinical Techniques of Equine Practice 5:112-126.

Speirs, V. C. 1999. O sistema alimentar. p.269-306. In: Exame clínico de equinos. Artmed, Porto Alegre.

Thompson, L. J. 1992. Heavy metal toxicosis. p.363-366. In: Current therapy in equine medicine. 3rd ed. Robinson, N. E., ed. W.B. Saunders, Philadelphia.

Topczewska, J. 2012. Effects of seasons on the concentration of selected trace elements in horse hair. Journal of Central European Agriculture 13:671-680.

Ward, N. I. and Savage, J.M. 1994. Elemental status of grazing animals located adjacent to the London Orbital (M25) motorway. Science of the Total Environment 146-147:185-189.

Wichert, B.; Frank, T. and Kienzle, E. 2002. Zinc, copper and selenium intake and status of horses in Bavaria. Journal of Nutrition 132:1776-1777. 